OPEN ACCESS

Edited by:

Risto Kasanen,

University of Helsinki, Finland

Reviewed by:

Nerea Abrego,

University of Jyväskylä, Finland

Ari Mikko Hietala,

Norwegian Institute of Bioeconomy

Research (NIBIO), Norway

*Correspondence:

Gitta Jutta Langer gitta.langer@nw-fva.de

tORCID:

Gitta Jutta Langer

orcid.org/0000-0002-9575-0423

Johanna Bußkamp

orcid.org/0000-0003-0891-175X

Specialty section:

This article was submitted to Microbe and Virus Interactions with

Plants,

a section of the journal

Frontiers in Microbiology

Received: 29 April 2021

Accepted: 05 August 2021

Published: 26 August 2021

Citation:

Langer GJ and Bußkamp J (2021)

Fungi Associated With Woody

Tissues of European Beech and Their

Impact on Tree Health.

Front. Microbiol. 12:702467.

doi: 10.3389/fmicb.2021.702467

\section{Fungi Associated With Woody Tissues of European Beech and Their Impact on Tree Health}

\author{
Gitta Jutta Langer*t and Johanna Bußkamp ${ }^{\dagger}$ \\ Section Mycology and Complex Diseases, Department of Forest Protection, Northwest German Forest Research Institute \\ (NW-FVA), Göttingen, Germany
}

Filamentous fungi associated with woody tissues of European Beech (Fagus sylvatica) and isolated from diseased trees and healthy trees were examined in relation to their impact on tree health. To this end, classical culture-based isolation methods, in planta inoculations and fungal identification using ITS-barcode and morphological characters were used. Stem endophytes of healthy beech saplings collected in German forests were isolated to determine endophyte communities in woody stem tissues. Pathogenicity tests were performed on living potted beech saplings using twelve selected fungal pathogens and wood inhabiting fungi (Hypocreales, Botryosphaeriales, and Xylariales) originating mainly from European beech with symptoms of the complex disease Vitality loss, or from bark necroses, or known to be common endophytes of beech. The impact of these ascomycetous fungi with respect to tree health was discussed. The potential influences of endophytic fungi of beech and of test conditions are discussed in relation to the success of inoculation. All tested fungal strains except for Neonectria ditissima were able to establish themselves post inoculation in the beech stems and caused necroses when there was sufficient water, but at different severities. Under the experimental conditions, Botryosphaeria corticola was shown to be the most virulent tested latent pathogen against $F$. sylvatica. In the context of climate change and global warming, the tested Botryosphaeriaceae are able to play a primary role in the disease progress of Vitality loss of Beech. The key role of Neonectria coccinea in causing bark necroses and the loss of vitality in beech was confirmed because the tested strain induced large lesions on the beech saplings.

Keywords: Fagus sylvatica, latent pathogens, virulence, pathogenicity, inoculation tests

\section{INTRODUCTION}

European beech (Fagus sylvatica L.) is one of the major tree species in Central Europe and has an important impact on the ecology and hydrogeology of forests (Danti et al., 2002). For example it is the most important broadleaved tree species in natural woodland vegetation and managed forests in Germany (BMEL, 2018). Beech forests are characteristic elements of the potential natural zonal vegetation of Germany (Tüxen and Preising, 1956; Ellenberg, 1996; Bohn et al., 2003), which means, 
that these vegetation types would prevail under current environmental conditions in the absence of human intervention. The German temperate, four-season climate is currently characterized by pronounced cold winters, generally overcast with limited precipitation, and warm summers. The latter are associated with a clear west-east cline in temperature. Therefore, summers vary regionally from hot and dry to cool and rainy (Bartsch et al., 2020). In recent decades, as a result of global warming, in Germany and worldwide, there has been a general trend toward higher temperatures [Deutscher Wetterdienst (DWD), Friedrich and Kaspar, 2019; Kaspar and Friedrich, 2020]. In Germany, the absolute annual mean temperature according to the Berkeley Earth averaging\% method is $8.3^{\circ} \mathrm{C}$. The linear temperature trend over the period 1881 to 2019 was $+1.6^{\circ} \mathrm{C}$ (Kaspar and Friedrich, 2020). The year 2018, with a mean temperature of $10.5^{\circ} \mathrm{C}$, was the warmest year recorded in Germany since the start of systematic observations in 1881 (Friedrich and Kaspar, 2019), followed by the years 2020 (10.4 ${ }^{\circ} \mathrm{C}$, Imbery et al., 2021) and $2019\left(10.3^{\circ} \mathrm{C}\right.$, Kaspar and Friedrich, 2020). In comparison to the international reference period 1961-1990, the annual mean temperature in 2018 was $+2.3^{\circ} \mathrm{C}$ higher (Friedrich and Kaspar, 2019). In addition, these three years were characterized by pronounced spring drought (Imbery et al., 2021) which, together with the extraordinary weather conditions throughout most months, resulted in root zone soil moisture and soil water storage deficits (Eichhorn et al., 2020; Tijdeman and Menzel, 2021). According to DWD, in 2018 the total annual precipitation was $590 \mathrm{l} / \mathrm{m}^{2}$ in Germany, regionally ranging from $250-1800 \mathrm{l} / \mathrm{m}^{2}$. As a result, the total precipitation across Germany in 2018 reached only $75 \%$ of the long term average $\left(789 \mathrm{l} / \mathrm{m}^{2}\right)$ relative to the reference period 1961-1990. In the year of our study, 2020, the total precipitation across Germany was $710 \mathrm{l} / \mathrm{m}^{2}$ (a deficit of -10\%) and in Lower Saxony it was only $689 \mathrm{l} / \mathrm{m}^{2}$ (a deficit of -13\%). Generally, periods of soil moisture drought stress can last longer than the meteorological drought that causes them and can have negative effects on plants or tree growth and health (Eichhorn et al., 2020; Tijdeman and Menzel, 2021).

Even though European beech has a wide climatic and geological amplitude, as well as high shade tolerance and growth capacity (Ellenberg, 1996; Bartsch et al., 2020), stands of it face loss of vitality due to ongoing climate change. This is because the climatic amplitude of this Atlantic to Subcontinental tree species, i.e., $4-12^{\circ} \mathrm{C}$ mean annual temperature and $450-$ 2000 1/ $\mathrm{m}^{2}$ rainfall Kölling (2007), reaches its limits regionally. The extraordinary weather conditions in the years 2018 to 2020 (Eichhorn et al., 2020; Imbery et al., 2021), including prolonged periods of high temperature, droughts and high levels of solar radiation, increased the vulnerability of European beech to fungal infection and beetle attacks, and triggered sun-scorch and the outbreak of complex diseases mainly caused by latent fungal pathogens (Langer et al., 2020). Loss of vitality and mortality of European beech have been observed and studied in several regions of Germany (Langer et al., 2020). In these studies, a number of fungi associated with woody tissues of European beech have been identified or isolated. Some of these were already known to be typical endophytes of beech woody tissues, such as Asterosporium asterospermum (Pers.) S. Hughes, Apiognomonia errabunda (Roberge ex Desm.) Höhn., Biscogniauxia nummularia (Bull.) Kuntze, Hypoxylon fragiforme (Pers.) J. Kickx f., and Neonectria coccinea (Pers.) Rossman and Samuels (Hendry et al., 2002; Parfitt et al., 2010; Senanayake et al., 2018; Langer et al., 2020). Some, however (e.g., Botryosphaeria corticola A.J.L. Phillips, A. Alves, and J. Luque), were found for the first time to be associated with the woody tissues of beech, or represented the first discovery on beech in Germany [Sphaeropsis sapinea (Fr.) Dyko and B. Sutton] (Langer et al., 2020).

Endophytes of $F$. sylvatica have previously been studied by several authors (e.g., Sieber and Hugentobler, 1987; Danti et al., 2002; Hendry et al., 2002; Baum et al., 2003; Sieber, 2007; Langer et al., 2021). Langer et al. (2020) examined an outbreak of Vitality Loss of European Beech (VLB) and found that endophytes, especially latent pathogens in the families Botryosphaeriaceae, Nectriaceae, Diaporthaceae and Xylariales, had a negative impact on tree health under the extreme weather conditions already mentioned.

In this study, 12 ascomycetous fungi associated with woody tissues of European beech were examined to shed light on the beech endophyte community and examine the impact on tree health. The aims of this study were (1) to confirm the pathogenicity and virulence in planta of latent fungal pathogens originally associated with bark necrosis or VLB, (2) to test virulence of the fungal species under field conditions in vital trees not exposed to drought stress, and (3) to determine whether there are interactions between beech stem endophytes and the inoculated pathogens. Therefore, the virulence of these endophytes in relation to the production of bark necroses and as potential pathogens of European beech was tested in inoculation tests involving potted beech saplings growing under field conditions.

\section{MATERIALS AND METHODS}

Twelve ascomycetous fungal strains originating from two different host species (Acer pseudoplatanus L. and Fagus sylvatica L.) sampled in Germany (Table 1) were tested on 1376 - 17 yearold (mean: 9.6 years old, estimated by year ring analysis of 20 saplings) potted Fagus sylvatica plants in a field study.

The saplings were excavated from a natural regeneration stand in March 2020 (origin: beech dominated mixed forest, Lower Saxony, Germany; $\left.51^{\circ} 35^{\prime} 39.7^{\prime \prime} \mathrm{N} 9^{\circ} 49^{\prime} 46.2^{\prime \prime} \mathrm{E}\right)$. The health of the saplings appeared to be very good at the beginning of the experiment and no symptoms of Vitality loss, bark necrosis or other disease symptoms were visible. The stem height of the saplings was $169-327 \mathrm{~cm}$ (mean $=260.5 \mathrm{~cm}, n=137)$ and the stem diameter $70 \mathrm{~cm}$ above ground was $0.96-2.05 \mathrm{~cm}$ (mean $=1.5 \mathrm{~cm}, n=137)$. The saplings were planted in $65 \mathrm{l}$ black plant pots containing potting compost (PROFI-LINIE Kleeschulte Topfsubstrat mineralisch: $\mathrm{pH} \mathrm{6}$, salinity $1.5 \mathrm{~g} / \mathrm{l}, \mathrm{N}$ total: $320 \mathrm{mg} / \mathrm{l}, \mathrm{P}_{2} \mathrm{O}_{5}: 120 \mathrm{mg} / \mathrm{l}, \mathrm{K}_{2} \mathrm{O}: 350 \mathrm{mg} / \mathrm{l}, \mathrm{Mg}: 120 \mathrm{mg} / \mathrm{l}$, Kleeschulte Erden GmbH \& Co. KG, Briloner Straße 14, D-59602 Rüthen, Germany). The 137 plants were randomly assigned to blocks and kept at natural air temperature (Tmean $17^{\circ} \mathrm{C}$, 
TABLE 1 | Pathogenicity tests: test strains, necrosis length, results of re-isolation.

\begin{tabular}{|c|c|c|c|c|c|c|c|c|c|c|}
\hline \multirow[t]{2}{*}{ Species } & \multirow[t]{2}{*}{ Strain } & \multirow{2}{*}{$\begin{array}{l}\text { Accession } \\
\text { No. }\end{array}$} & \multirow{2}{*}{$\begin{array}{l}\text { Year of } \\
\text { isolation }\end{array}$} & \multirow{2}{*}{$\begin{array}{l}\text { Original } \\
\text { host tree }\end{array}$} & \multirow[t]{2}{*}{ Host tissue } & \multirow{2}{*}{$\begin{array}{l}\text { Necrosis length (mm, } \\
\text { arithmetic mean of } \\
\text { nine studied trees) }\end{array}$} & \multirow[t]{2}{*}{ Reaction of host tissue } & \multicolumn{3}{|c|}{ Re-isolation from inoculated tissue after 4 months } \\
\hline & & & & & & & & $\begin{array}{c}\text { Re-isolation } \\
\text { of test } \\
\text { species }\end{array}$ & $\begin{array}{c}\text { isolated } \\
\text { filamentous } \\
\text { morphotypes (MTs) }\end{array}$ & $\begin{array}{l}\text { additional } \\
\text { isolated } \\
\text { filamentous fungi }\end{array}$ \\
\hline $\begin{array}{l}\text { Biscogniauxia } \\
\text { mediterranea }\end{array}$ & $\begin{array}{l}\text { NW-FVA } \\
5283\end{array}$ & MT561410 & 2019 & F. sylvatica & $\begin{array}{l}\text { wood of twig with } \\
\text { dieback } \\
\text { symptoms }\end{array}$ & 11.3 & $\begin{array}{l}\text { Necrotic lesions } \\
\text { visible, mostly no } \\
\text { callus formation }\end{array}$ & yes & 3 & e.g., N. coccinea \\
\hline $\begin{array}{l}\text { Biscogniauxia } \\
\text { nummularia }\end{array}$ & $\begin{array}{l}\text { NW-FVA } \\
5282\end{array}$ & MT561409 & 2019 & F. sylvatica & $\begin{array}{l}\text { wood of twig with } \\
\text { dieback } \\
\text { symptoms }\end{array}$ & 13.9 & $\begin{array}{l}\text { Necrotic lesions } \\
\text { visible, no callus formation }\end{array}$ & yes & 2 & N. coccinea \\
\hline $\begin{array}{l}\text { Botryosphaeria } \\
\text { corticola }\end{array}$ & $\begin{array}{l}\text { NW-FVA } \\
4897\end{array}$ & MN698983 & 2019 & F. sylvatica & $\begin{array}{l}\text { fruiting body } \\
\text { on bark }\end{array}$ & $69.8 *$ & $\begin{array}{l}\text { Large Necrotic } \\
\text { lesions visible, } \\
\text { no callus formation, } \\
\text { orange-brownish discolorations } \\
\text { in the whole stem }\end{array}$ & yes & 1 & none \\
\hline $\begin{array}{l}\text { Botryosphaeria } \\
\text { dothidea }\end{array}$ & $\begin{array}{l}\text { NW-FVA } \\
5287\end{array}$ & MZ045841 & 2019 & $\begin{array}{l}\text { Fagus } \\
\text { sylvatica }\end{array}$ & wood trunk & 11.6 & $\begin{array}{l}\text { Necrotic lesions } \\
\text { visible, T-shaped discoloration, } \\
\text { inoculation locus } \\
\text { of some trees overgrown by } \\
\text { callus formation, }\end{array}$ & yes & 3 & e.g., N. coccinea \\
\hline $\begin{array}{l}\text { Botryosphaeria } \\
\text { stevensii }\end{array}$ & $\begin{array}{l}\text { NW-FVA } \\
4915\end{array}$ & MN698981 & 2019 & F. sylvatica & wood trunk & 12.8 & $\begin{array}{l}\text { Necrotic lesions } \\
\text { visible, no or minor callus } \\
\text { formation }\end{array}$ & yes & 4 & $\begin{array}{l}\text { e.g., N. coccinea, } \\
\text { Sordaria sp. }\end{array}$ \\
\hline $\begin{array}{l}\text { Eutypella } \\
\text { quaternata }\end{array}$ & $\begin{array}{c}\text { NW-FVA } \\
5333\end{array}$ & MZ045842 & 2019 & F. sylvatica & ascocarp on bark & 19.3 & $\begin{array}{l}\text { Necrotic lesions } \\
\text { visible, no callus formation }\end{array}$ & yes & 3 & e.g., N. coccinea \\
\hline $\begin{array}{l}\text { Hypoxylon } \\
\text { fragiforme }\end{array}$ & $\begin{array}{l}\text { NW-FVA } \\
5174\end{array}$ & $\begin{array}{l}\text { Species } \\
\text { identical with } \\
\text { MZ045852 }\end{array}$ & 2019 & $\begin{array}{l}\text { Fagus } \\
\text { sylvatica }\end{array}$ & wood trunk & 10.4 & $\begin{array}{l}\text { Necrotic lesions } \\
\text { visible, with callus formation, } \\
\text { T-shaped discoloration }\end{array}$ & yes & 4 & e.g., N. coccinea \\
\hline $\begin{array}{l}\text { Nectria } \\
\text { cinnabarina }\end{array}$ & $\begin{array}{l}\text { NW-FVA } \\
1249\end{array}$ & MZ045843 & 2012 & $\begin{array}{l}\text { A. pseudo- } \\
\text { platanus }\end{array}$ & $\begin{array}{l}\text { stem } \\
\text { necrosis }\end{array}$ & $23.0 * *$ & $\begin{array}{l}\text { Necrotic lesions } \\
\text { visible, no callus formation }\end{array}$ & yes & 3 & e.g., N. coccinea \\
\hline $\begin{array}{l}\text { Neonectria } \\
\text { coccinea }\end{array}$ & $\begin{array}{l}\text { NW-FVA } \\
5096\end{array}$ & MN698988 & 2019 & F. sylvatica & $\begin{array}{l}\text { stem } \\
\text { necrosis }\end{array}$ & 17.9 & $\begin{array}{l}\text { Necrotic lesions } \\
\text { visible, no callus formation }\end{array}$ & yes & 2 & e.g., Zygomycota. \\
\hline $\begin{array}{l}\text { Neonectria } \\
\text { ditissima }\end{array}$ & $\begin{array}{l}\text { CBS } \\
226.31\end{array}$ & JF735309 & 1925 & F. sylvatica & bark & 10.7 & $\begin{array}{l}\text { Necrotic lesions } \\
\text { visible, T-shaped discoloration, } \\
\text { with callus formation }\end{array}$ & no & 3 & $\begin{array}{l}\text { e.g., E. quaternata, } \\
\text { Clitopilus sp. } \\
\text { (MZ045857) }\end{array}$ \\
\hline $\begin{array}{l}\text { Neonectria } \\
\text { aff. coccinea }\end{array}$ & $\begin{array}{l}\text { NW-FVA } \\
0179\end{array}$ & MZ057618 & 2009 & F. sylvatica & $\begin{array}{l}\text { stem } \\
\text { necrosis }\end{array}$ & 16.4 & $\begin{array}{l}\text { Necrotic lesions } \\
\text { visible, no callus formation }\end{array}$ & yes & 3 & e.g., Fusarium sp. \\
\hline $\begin{array}{l}\text { Sphaeropsis } \\
\text { sapinea }\end{array}$ & $\begin{array}{l}\text { NW-FVA } \\
4932\end{array}$ & MN698984 & 2019 & F. sylvatica & wood trunk & 10.7 & $\begin{array}{l}\text { Necrotic lesions } \\
\text { visible, T-shaped discoloration, } \\
\text { with callus formation }\end{array}$ & yes & 5 & $\begin{array}{l}\text { e.g., Diaporthe sp., } \\
\text { Fusarium sp., } \\
\text { Clitopilus sp. } \\
\text { (MZ045858) }\end{array}$ \\
\hline
\end{tabular}




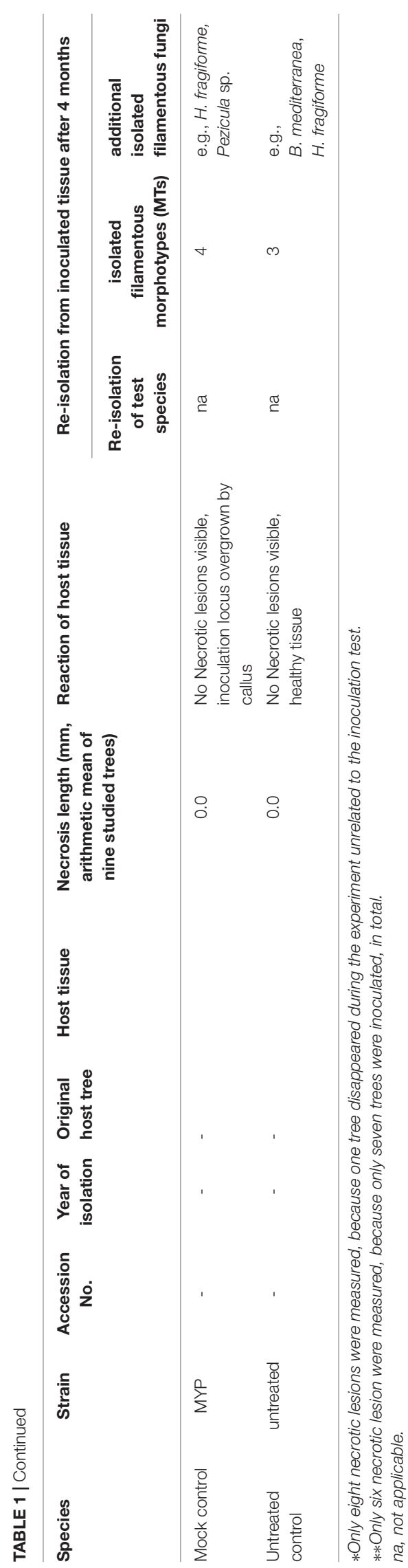

Tmin. $4^{\circ} \mathrm{C}$ and $\operatorname{Tmax} .35^{\circ} \mathrm{C}$ ). They were watered regularly via a Drip irrigation system (Friesecke Bewässerungstechnik GmbH, Leineweberstr. 7, 31303 Burgdorf, Germany) and shaded by surrounding older trees. During the experiment the watering regime was adjusted to supply the saplings with the optimal amount of water and air temperatures were measured by a $\mathrm{HOBO}^{\circledR}$ Pro v2 data logger. The endophyte community in the woody tissues of the plant material collected from the natural beech regeneration site was determined prior to the experiment. Three saplings were examined to determine whether there was pre-colonization of the internal tissues by the test species and to profile the endophyte community. After surface disinfection with a 70\% ethanol spray, stem bark and small wood chips (89 inocula, max. $0.5 \times 0.5 \mathrm{~cm}$ in size) were obtained and placed in Petri dishes with culture medium, then incubated at room temperature in daylight. They were cultivated on malt yeast peptone agar (MYP), modified according to Langer (1994), containing 0.7\% malt extract (Merck 1.05391.0500, Darmstadt, Germany), 0.05\% yeast extract (Fluka 70161-100G, Seelze, Germany), 0.1\% peptone (Merck 1.07272.0500), and 1.5\% agar (Fluka 05040-1KG). The Petri dishes were checked periodically for emerging mycelia, which were subsequently sub-cultured on fresh MYP medium to obtain pure cultures. Isolated, representative fungal strains were kept on MYP slants at $4^{\circ} \mathrm{C}$.

Following Bußkamp et al. (2020), isolated endophytic strains were assigned to morphotypes and identified on the basis of micro-morphological characters and/or sequencing of the ITS15.8S-ITS2 region of rDNA (White et al., 1990). At least one representative strain of each morphotype was used for molecular identification, involving DNA extraction from the mycelium, following Izumitsu et al. (2012), then PCR and sequencing of the target region. Sequences obtained were aligned and manually edited using MEGA5 software (Tamura et al., 2011), then used in BLAST searches of the GenBank databases (Altschul et al., $1997^{1}$ ) to identify similar ITS sequences. A similarity threshold of $98 \%$ was set for species-level identification. Generally, morphological characteristics were used to confirm the results of molecular identification.

With the exception of Neonectria ditissima (CBS 226.31) all fungal strains used in our pathogenicity tests were isolated from material associated with cases of disease from Germany that have been studied by the NW-FVA. Apart from Nectria cinnabarina (NW-FVA 1249, isolated from sycamore in Lower Saxony) all tested strains were isolated from woody tissues or bark necrotic tissue of diseased European beech trees following the procedure described above for endophytes from fruiting bodies growing on these trees. They were identified based on morphology and ITS sequencing. The ITS sequences (containing ITS1, 5.8S, and ITS2 regions) have been deposited in GenBank (Table 1) and all of the strains are permanently stored in the NW-FVA strain collection. The test strains (Table 1) included species of Botryosphaeriaceae (Botryosphaeria corticola, anamorph: Diplodia corticola A.J.L. Phillips, A. Alves and J. Luque, NW-FVA 4897: Hesse); B. dothidea (Moug.) Ces. and De Not., anamorph: Fusicoccum aesculi Corda, NW-FVA 5287: Saxony-Anhalt;

\footnotetext{
${ }^{1}$ http://www.ncbi.nlm.nih.gov/genbank/
} 
B. stevensii Shoemaker, anamorph: Diplodia mutila (Fr.) Mont., NW-FVA 4915, Hesse; and Sphaeropsis sapinea, synonym: Diplodia sapinea (Fr.) Fuckel (teleomorph not known, NW-FVA 4932, Hesse), Diatrypaceae [Eutypella quaternata (Pers.) Rappaz, anamorph: Libertella faginea Desm., NW-FVA 5333, Hesse], Graphostromataceae [Biscogniauxia mediterranea (De Not.) Kuntze, NW-FVA 5287 and B. nummularia (Bull.) Kuntze, NW-FVA 5282, both with Nodulisporium-like anamorph and collected in Saxony-Anhalt], Hypoxylaceae [Hypoxylon fragiforme (Pers.) J. Kickx f., anamorph: Nodulisporium ochraceum Preuss, NW-FVA 5174: Saxony-Anhalt], and Nectriaceae [Neonectria ditissima (Tul. and C. Tul.) Samuels and Rossman = Neonectria galligena (Bres.) Rossman and Samuels, anamorph: Cylindrocarpon heteronema (Berk. and Broome) Wollenw. = Cylindrocarpon willkommii (Lindau) Wollenw.: Saxony; Neo. coccinea, anamorph: Cylindrocarpon candidum (Link) Wollenw., NW-FVA 5096: Hesse; Neo. aff. coccinea, NW-FVA 0179, Schleswig-Holstein), and Nectria cinnabarina, anamorph: Tubercularia vulgaris Tode: Schleswig-Holstein].

To estimate the impact of the test strains on European beech health, pathogenicity tests were conducted according to Henle-Koch postulates (Evans, 1976) and necrosis length was measured. The inoculation experiments were performed at the nursery of the NW-FVA in Hann. Münden, southern Lower Saxony, Germany $\left(51^{\circ} 25^{\prime} 38.7^{\prime \prime} \mathrm{N} 9^{\circ} 38^{\prime} 18.6^{\prime \prime} \mathrm{E}\right)$ from 26.05.2020 until 30.09.2020 (4 months). For each tested strain (except N. cinnabarina), ten saplings were inoculated with an MYP-agar plug of a one-week-old culture of the fungus. The plugs were placed in wounds made with a sterile cork borer ( $5 \mathrm{~mm}$ diameter) in the stem at a height of $70 \mathrm{~cm}$. The removed bark was replaced on top of the plug, then the stem was wrapped with Parafilm. A set of 10 untreated controls, trees which were not inoculated at all, and mock controls, prepared by inoculating 10 trees with a sterile pure culture medium plug of MYP, were created. After 4 weeks (29.06.2020) one sapling per treatment group was sampled to check infection success and necrosis formation. The bark around the area of inoculation was peeled away to allow us to see and measure the extent of any necroses. Lesion lengths were measured with a ruler in the vertical direction to an accuracy of $1 \mathrm{~mm}$. Fungi were re-isolated from discolored and non-discolored tissue and the resulting isolates were identified. The pathogenicity tests ended four months after inoculation with the twelve potential latent pathogens. The impact on tree health of each strain was estimated on the basis of the size of the necrotic lesions. In addition, the reaction of the host tissue, such as healing over, formation of a callus, or T-shaped discolorations, was recorded. The latter are dark or black colored T-shaped defects/discoloration of the wood, visible in a crosssection of the stem, caused by healing over of a wound or bark necrosis. Statistical differences in length of the necrotic area between different strains and controls were investigated using ANOVA and Tukey's HSD post hoc test. All data analysis was conducted in R, version 3.6.2 (R Core Team, 2019). Differences were considered statistically significant if their $\mathrm{p}$-value was below the threshold of 0.01 . To confirm the infection and to guarantee that Koch's postulates were fulfilled, pieces from the interface between necrotic and healthy tissue of one sapling collected in June and 3 - 7 saplings collected in September from each treatment group were surface sterilized (as described above) and plated on MYP agar. In total, 87 tissue samples, an average of 6.9 inocula per tested tree, were incubated in June (one month post inoculation) and 306 samples, an average of 5.9 inocula per tested tree, in September (four months post inoculation) were incubated for 4 weeks in an effort to re-isolate the inoculated strain. Re-isolated fungi were identified morphologically.

\section{RESULTS}

\section{Pre-experiment - Isolation of Beech Stem Endophytes}

In total, we were able to isolate 18 filamentous, endophytic fungal species from the 89 inocula retrieved from stem bark and wood of the three beech saplings sampled at the beginning of the study (Table 2). Three species were isolated from all three studied trees: Diaporthe sp. 2, Hypoxylon fragiforme, and Coniochaeta sp. Three species were isolated from two saplings: Chaetomium sp. 1, Diaporthe sp. 1, and Talaromyces sp. Twelve fungi were found in only one of the three saplings: ascomycetous species 1_5481, ascomycetous species 2_5482, ascomycetous species 3_5484 and ascomycetous species 4_5490, Chaetomium sp. 2, Coprinellus micaceus, Diaporthe sp. 3, Hypoxylon rubiginosum (Pers.) Fr., Jackrogersella cohaerens (Pers.) L. Wendt, Kuhnert and M. Stadler, Lepteutypa fuckelii Petr., Nigrospora oryzae (Berk. and Broome) Petch, and Penicillium glandicola (Oudem.) Seifert and Samson. All the species that were shown to be present as endophytes, with the exception of the white-rot fungus Coprinellus micaceus (Bull.) Vilgalys, Hopple and Jacq. Johnson, Agaricaceae Basidiomycota, were members of the Ascomycota. Only one of the test species for the inoculation tests, $H$. fragiforme, was isolated as an endophyte from beech stems.

\section{Pathogenicity Tests}

Four weeks post inoculation, necrosis formation was not obvious in any of the trees inoculated with the test strains. In untreated and mock controls no necrotic lesions were visible and no fungi could be isolated from the beech tissue in the area of inoculation. Apart from Neonectria ditissima, all the species used for inoculation could be isolated from the inoculated saplings four months after treatment (Table 1). In addition to the inoculated species, ten other fungi associated with the samples were isolated, these can be regarded as naturally occurring endophytes (Table 1). Three different fungal endophytes, including $B i$. mediterranea and $H$. fragiforme were isolated from the untreated controls. From the mock-controls, four different fungal species were isolated, including $H$. fragiforme. In both control types no strains of the other inoculated species were shown to be present as endophytes. No additional endophytic species were isolated from the saplings inoculated with Bo. corticola, while from the saplings inoculated with Neo. coccinea only Zygomycota strains were recorded. Neo. coccinea was also isolated from the saplings inoculated with Bi. mediterranea, Bi. nummularia, Bo. dothidea, Bo. stevensii, E. quaternata, $H$. fragiforme, and Nec. cinnabarina. E. quaternata and Clitopilus sp. (Basidiomycota) were isolated 
TABLE 2 | Pre-isolation of stem woody and bark tissues of three Fagus sylvatica saplings.

\begin{tabular}{|c|c|c|c|c|c|c|c|}
\hline NW-FVA No. & Accession No. & Species & Best match blast 23.04.2021 & Accession No. & Sapling 1 & Sapling 2 & Sapling 3 \\
\hline 5481 & na & $\begin{array}{l}\text { ascomycetous } \\
\text { species } 1\end{array}$ & Not amplified & & 1 & & \\
\hline 5482 & na & $\begin{array}{l}\text { ascomycetous } \\
\text { species } 2\end{array}$ & Not amplified & & & & 1 \\
\hline 5485 & na & $\begin{array}{l}\text { ascomycetous } \\
\text { species } 3\end{array}$ & Not amplified & & & & 1 \\
\hline 5490 & MZ045844 & $\begin{array}{l}\text { ascomycetous } \\
\text { species } 4\end{array}$ & Lophiostoma corticola & KU712227 & 1 & & \\
\hline 5466 & MZ045845 & Chaetomium sp.1 & Chaetomium sp. & MN341311 & 1 & & 1 \\
\hline 5471 & MZ045846 & Chaetomium sp. 2 & Fungal sp. & KF212321 & & 1 & \\
\hline 5467 & MZ045847 & Coniochaeta sp. & Coniochaeta sp. & MT644317 & 1 & 1 & 1 \\
\hline 5478 & MZ045848 & $\begin{array}{l}\text { Coprinellus } \\
\text { micaceus }\end{array}$ & Coprinellus micaceus & MF161199 & & & 1 \\
\hline 5458 & MZ045849 & Diaporthe sp. 1 & Diaporthe viticola & KC145906 & 1 & & 1 \\
\hline 5473 & MZ573778 & Diaporthe sp. 2 & Diaporthe eres & MH931269 & 1 & 1 & 1 \\
\hline 5486 & MZ045851 & Diaporthe sp. 3 & Diaporthe melonis & MW308548 & 1 & & \\
\hline 5465 & MZ045852 & $\begin{array}{l}\text { Hypoxylon } \\
\text { fragiforme }\end{array}$ & Hypoxylon fragiforme & EF155528 & 1 & 1 & 1 \\
\hline 5494 & MZ045853 & $\begin{array}{l}\text { Hypoxylon } \\
\text { rubiginosum }\end{array}$ & Hypoxylon rubiginosum & MT214998 & & & 1 \\
\hline 5492 & MZ045854 & $\begin{array}{l}\text { Jackrogersella } \\
\text { cohaerens }\end{array}$ & Annulohypoxylon cohaerens & EF026140 & 1 & & \\
\hline 5470 & MZ045855 & Lepteutypa fuckelii & Lepteutypa fuckelii & NR_154123.1 & & 1 & \\
\hline 5460 & MZ045856 & Nigrospora oryzae & Nigrospora oryzae & MG098254 & 1 & & \\
\hline 5461 & na & Penicillium sp. & Not amplified & & & 1 & \\
\hline 5472 & MZ045914 & Talaromyces sp. & Talaromyces verruculosus & MH398576 & & 1 & 1 \\
\hline \multicolumn{4}{|c|}{ In total: 18 Morphotypes } & sum & 10 & 7 & 10 \\
\hline
\end{tabular}

na, not applicable.

from the saplings inoculated with Neo. ditissima. As well as Fusarium sp. and Diaporthe sp., the same Clitopilus sp. was isolated from the saplings inoculated with S. sapinea.

The months during which the field experiment took place were significantly warmer in Germany than the long-term mean for the international reference period 1961-1990 (NW-FVA, 2021). The mean air temperature of Lower Saxony was $16.6^{\circ} \mathrm{C}(+2.1$ compared to the mean) in June, $17.5^{\circ} \mathrm{C}\left(-0.1^{\circ}\right.$ compared to the mean) in July, $20.1^{\circ} \mathrm{C}\left(+3.6^{\circ}\right.$ compared to the mean) in August, and $14.5^{\circ} \mathrm{C}\left(+1^{\circ}\right.$ compared to the mean) in September. During the pathogenicity tests the mean air temperature was $17^{\circ} \mathrm{C}$ and 42 days with air temperatures over $25^{\circ} \mathrm{C}$, including 8 days $\geq 30^{\circ} \mathrm{C}$ were recorded at Hann. Münden. The total mean precipitation in Lower Saxony was $25 \mathrm{l} / \mathrm{m}^{2}$ ( $-59 \%$ compared to the mean) in May, $16.6^{\circ} \mathrm{C}\left(-8 \%\right.$ compared to the mean) in June, $65 \mathrm{l} / \mathrm{m}^{2}(-11 \%$ compared to the mean) in July, $65 \mathrm{l} / \mathrm{m}^{2}(-7.1 \%$ compared to the mean) in August, and $45 \mathrm{l} / \mathrm{m}^{2}$ (25\% of the mean) in September.

At the end of the experiment, all saplings were still alive but exhibiting different reactions to the various treatments (Table 1 and Figures 1, 2). In the untreated controls, no lesions were visible and the tissues were healthy. In the tissue surrounding the inoculation areas of the Mock control no lesions were visible either and the inoculation locus was overgrown by callus. All inoculated strains caused necrotic lesions with or without callus formation and with or without T-shaped discolorations. Trees inoculated with $B$. corticola exhibited the largest necrotic areas, and these were significantly larger than all other lesions (68 $\mathrm{mm}$ arithmetic mean necrosis length, Figure 2) and no callus formation had occurred within four months. In addition, in these saplings an orange-brownish discoloration was visible in the whole stem. The second longest lesions were present on saplings inoculated with Nec. cinnabarina $(23 \mathrm{~mm})$, followed by saplings inoculated with E. quaternata (19.3 mm), Neo. coccinea (17.9 mm), Neo. aff. coccinea (16.4 mm), Bi. nummularia (13.9 mm), Bo. stevensii (12.8 mm), Bo. dothidea (11.6 mm), Bi. mediterranea $(11.3 \mathrm{~mm})$, Neo. ditissima (10.7 mm), S. sapinea $(10.7 \mathrm{~mm})$, and $H$. fragiforme $(10.4 \mathrm{~mm})$. Occlusion of the wounds caused by the cork borer was observed in some or all treated saplings inoculated with Bi. mediterranea, Bo. dothidea, Bo. stevensii, $H$. fragiforme, Neo. ditissima, and S. sapinea within four months. As well as for Bo. corticola, no healing over within four months was recorded in the saplings inoculated with Nec. cinnabarina, Neo. coccinea, Neo. aff. coccinea, Bi. nummularia, and E. quaternata. T-shaped discolorations were visible in saplings inoculated with Bo. dothidea, H. fragiforme, Neo. ditissima, and S. sapinea.

\section{DISCUSSION}

With the exception of the mock-controls, all inoculations with fungal mycelium via wounding led to the presence of necrotic 

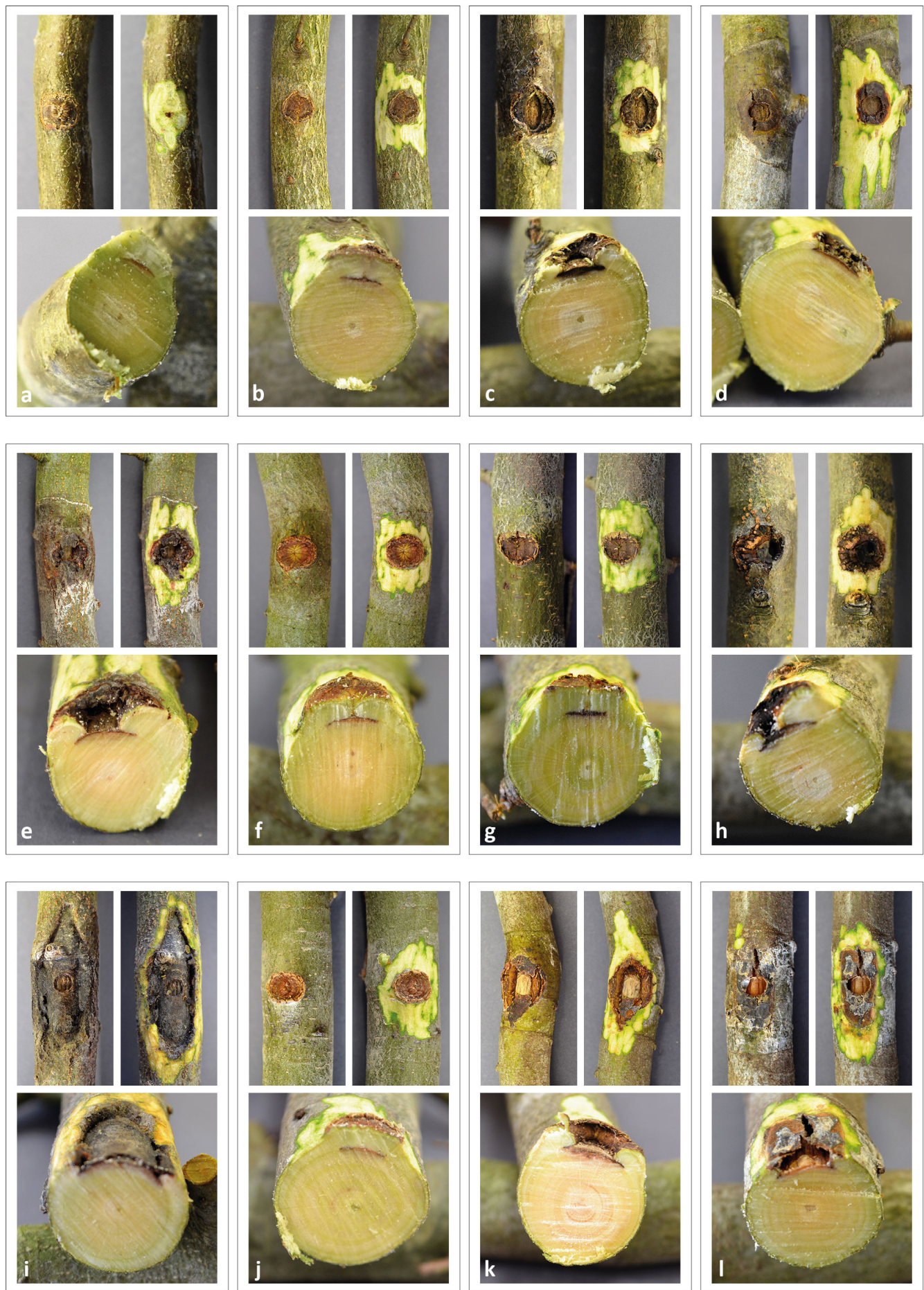

FIGURE 1 | Pathogenicity tests - Necrosis induced in saplings of European beech inoculated by different fungi. (a) Mock control, (b) Hypoxylon fragiforme,

(c) Biscogniauxia mediterranea, (d) Biscogniauxia nummularia, (e) Eutypella quaternata, (f) Sphaeropsis sapinea, (g) Botryosphaeria dothidea, (h) Botryosphaeria stevensii, (i) Botryosphaeria corticola, (j) Neonectria ditissima, (k) Neonectria coccinea, (I) Nectria cinnabarina.

lesions. In some cases wounds with fungal inoculation were able to heal completely or nearly so within four months; the species for which this happened included Bi. mediterranea, $H$. fragiforme, Neo. ditissima, and S. sapinea. This suggests a lower virulence compared to the other test strains. These fungal strains could, at least, be quiescent colonizers functioning as endophytes after the wounds have healed. Our results showing that all of the tested fungal species induced necrosis in the saplings are not 


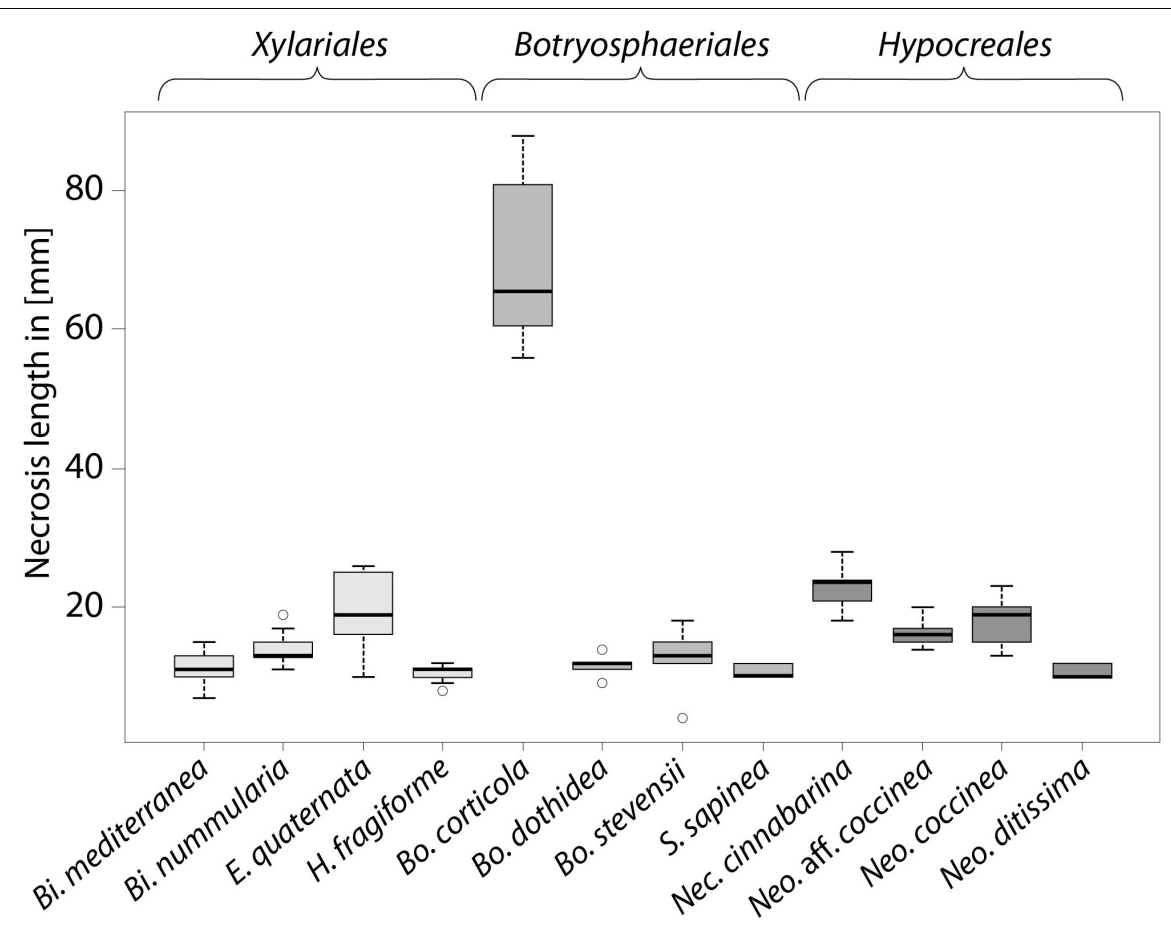

FIGURE 2 | Length of necrosis induced in saplings of European beech inoculated by different fungi, boxplot of lesion length.

surprising because they are known to be latent pathogenic wooddecaying fungi of $F$. sylvatica or common pathogens of other tree species. Nevertheless, a single stem infection via wounding and inoculation of a beech sapling with the test species was not sufficient to kill the whole the tree within the four months of the experiment. With the exception of Neo. ditissima, all test strains could be re-isolated, indicating successful infection by these strains and establishment in the woody tissue. In the following, the fungi examined are discussed mainly in the order of induced necrosis length.

\section{Botryosphaeria corticola}

The most prominent and longest necrotic lesions were caused by Bo. corticola, which differs from the other tested Botryosphaeriaceae in its virulence with regard to $F$. sylvatica. Bo. corticola is a latent plant pathogen which has been isolated at high frequency from physiologically impaired trees (Panzavolta et al., 2017). It is associated with oak decline in the Mediterranean area (Linaldeddu et al., 2014; Panzavolta et al., 2017) and causes cankers on stems, branches and twigs of oak trees ("Bot canker of oak," Dreaden et al., 2011) and dieback of oak (Smahi, 2017). As well as its distribution in the Iberian Peninsula, Italy, Algeria, and North America (Alves et al., 2004; Dreaden et al., 2011; Smahi, 2017), Bo. corticola was recently found on F. sylvatica in Germany (Langer et al., 2020). The Bo. corticola test strain used in our study was the first record of this species in Germany; it was isolated from diseased mature European beech, causing bleeding spots and bark necroses (Langer et al., 2020). Preliminary investigations on pathogenicity and virulence of Botryosphaeriaceae in relation to cut branches of European beech saplings in a greenhouse experiment were performed by Langer and Bußkamp (2021). They showed that necrosis length due to inoculated Botryosphaeriaceae was positively correlated with the lesion width. Within three weeks of incubation at a mean temperature of $25^{\circ} \mathrm{C}$, the length of necrotic lesions caused by Bo. corticola (mean: $58.3 \mathrm{~mm}$ ) was smaller than those caused by Bo. stevensii (mean: $73.1 \mathrm{~mm}$ ), while branches inoculated with $S$. sapinea showed no visible lesions. The results of our study suggest that with an adequate water supply and the mean air temperature of $17^{\circ} \mathrm{C}$ maintained during the experiment, $B$. corticola is significantly more virulent as a wound pathogen than Bo. stevensii. The inoculation experiments in planta showed, that Bo. corticola can be a highly virulent wound pathogen of European beech. If it should turn out that Bo. corticola is a frequent endophyte of European beech, there is an increased risk in the context of climate change or global warming, since it is a weak pathogen with optimal growth in vitro at $25^{\circ} \mathrm{C}$ (Smahi, 2017) and it is able to cause large necrotic lesions during in planta experiments and causes bark necrosis and bleeding spots under natural conditions. In the context of Vitality loss of European beech (VLB, Langer et al., 2020), Bo. corticola may play an important role as one of the first major fungal causal agents in the disease progression.

\section{Nectria cinnabarina}

Nectria cinnabarina, also known as coral spot (Line, 1922), is a weak pathogen and later a saprophyte of Beech. Its ability to cause cankers and dieback on broadleaved trees (Line, 1922; Hirooka et al., 2011) was confirmed by our results: on saplings inoculated with Nec. cinnabarina, the second longest necrotic lesions and 
no healing over were observed within four months. Normally, Nec. cinnabarina invades hosts via wounds by spreading through the wood cells from dead tissue into the living xylem. Xylem is blocked by the fungal hyphae, leading to wilting and death of all parts above the infection site (Line, 1922). However, whether the necroses were really caused by Nec. cinnabarina alone is questionable, since Neo. coccinea was also isolated in the area of the inoculation.

\section{Eutypella quaternata}

Eutypella quaternata is a common bark fungus on European beech in Germany, fruiting on dead branches (Vasilyeva and Scheuer, 1996; Vasilyeva, 2011) and dead bark on the living stem. This fungus is considered to be a weak parasite and saprobiont and often occurs together with Neo. coccinea (Langer and Bußkamp, 2021). Successful infection by E. quaternata of the studied beech saplings was confirmed by re-isolation and, astonishingly, it produced the third longest necrotic lesions in the entire experiment. Whether the lesions were really caused by E. quaternata alone is questionable, since Neo. coccinea was also isolated in the area of the inoculation. It is conceivable that the inoculation and infection with E. quaternata led to the transition of Neo. coccinea from its latent, dormant phase to the active, parasitic phase, with the two species together causing necrosis. The two species could have a positive synergistic influence on each other with regard to their ability to cause necrosis, since the lesions observed were significantly longer than on the saplings that only had an infection with Neo. coccinea. E. quaternata was also isolated from saplings inoculated with Neo. ditissima. It can be assumed that E. quaternata is a xylariaceous endophyte of beech, waiting to decompose the host cell wall compounds when its hosts are senescent or exhibit poor vigor (Petrini and Petrini, 1985; Whalley, 1996).

\section{Neonectria coccinea and Neo. aff. coccinea}

The xylem endophyte Neo. coccinea is one of the most common fungi that remains latent in healthy woody tissues of Fagus in Europe (Chapela and Boddy, 1988; Chapela, 1989; Castlebury et al., 2006). We, therefore, expected Neo. coccinea to be found as an endophyte in the pre-experiment; this was not the case. This fungus was, however, found to be associated with the necrotic tissues in almost all other pathogenicity tests with other inoculated fungi, although it was not isolated from the stem tissues of the saplings in the pathogenicity tests with Bo. corticola or Neo. ditissima, or from the mock-controls and untreated controls. The growth of Neo. coccinea thalli is probably inhibited by low oxygen and/or nutrient availability (Sieber, 2007; Rodríguez et al., 2011). Neo. coccinea is one of the key fungal causal agents of BBD (Langer, 2019) and VLB (Langer, 2019; Langer et al., 2020; Langer and Bußkamp, 2021), whereas Neo. ditissima takes over this function in the progression of BBD in North America (Castlebury et al., 2006). Neo. coccinea can also cause necrotic lesions in the bark of beech branches without previous colonization by the beech-bark scale Cryptococcus fagisuga Lindinger (Niesar et al., 2007; Langer et al.,
2020). According to Castlebury et al. (2006), there are additional, undescribed Neonectria species related to Neo. coccinea and Neo. punicea (J.C. Schmidt) Castl. and Rossman occurring on beech in Europe. The tested strain, NW-FVA 0179, was intermediate between the two latter species with respect to its ITS region. For further studies, we consider that it will be crucial to determine the Neo. aff. coccinea involved more precisely using the methods of Karadžić et al. (2020). Both test strains NW-FVA 5096 and NW-FVA 0179 caused necrotic lesions of more less equal size, no callus formation was observed within four months and no other typical necrosis pathogens could be found during re-isolation. We, therefore, assume that strains of the Neo. coccinea group have a high capacity to cause necrosis and may lead to tree mortality. Under conditions associated with global warming, increased damage caused by Neo. coccinea is to be expected, since strains of this species exhibit robust, rapid mycelial growth at $30^{\circ} \mathrm{C}$ in vitro (Hirooka et al., 2013).

Under the environmental conditions encountered in our experiment, inoculation via wounding and application of mycelium do not lead to symptomless infection of the samplings. However, we also isolated Neo. coccinea from the necrotic areas in our pathogenicity tests involving other fungi (Bi. mediterranea, Bi. nummularia, Bo. dothidea, Bo. stevensii, E. quaternata, $H$. fragiforme, and Nec. cinnabarina) because the species is able to overgrow necrotic tissues induced by other fungi (Niesar et al., 2007) after activation of a dormant propagule The reason why we were unable to isolate Neo. coccinea as an endophyte in the pre-experiment remains unclear. We also still need to determine whether the additional species also isolated have an influence on the virulence of the inoculated species and which fungus, the inoculated strain or the endophyte such as Neo. coccinea, $H$. fragiforme or E. quaternata induced the necrosis. It should be noted here that many distinct genotypes of $H$. fragiforme and Neo. coccinea have been found to be present within small areas in the woody tissues of their hosts (Hendry et al., 2002). According the latter authors, the development of fungal species after the sapwood of their hosts has been injured or subjected to water stress is mainly influenced by the low oxygen tension persisting after damage. The main factor that stimulates the active growth of latent fungal units in their host tissues appears to be aeration (Hendry et al., 2002). Species that are known to be early colonizers, such as Bi. nummularia, $H$. fragiforme, and Neo. coccinea, can tolerate low oxygen tension and are selectively favored by these environmental conditions. The balance between endophytic strains and inoculated strains is affected by temperature. While the occurrence of Bi. nummularia and $H$. fragiforme was evenly distributed at temperatures of $25^{\circ} \mathrm{C}$, $B i$. nummularia occurred more frequently at higher temperatures around $30^{\circ} \mathrm{C}$.

\section{Biscogniauxia nummularia and Bi. mediterranea}

Biscogniauxia nummularia is one of the most common endophytes and latent pathogens of woody tissues of European beech (Chapela and Boddy, 1988; Chapela, 1989). The results of our pathogenicity tests revealed the ability of Bi. nummularia 
to cause necrosis on European beech in planta, which fits the results of Nugent et al. (2005) and observations in nature (Langer and Bußkamp, 2021). The inoculated saplings supplied with sufficient water exhibited necrosis, even though water deficit can be a main factor to predispose the plant to disease (Boyer, 1995). Derived from healthy functional beech xylem tissue, Bi. nummularia can take advantage of altered host physiology and cause strip-cankers, bark blisters, bark ruptures, and wood-decay on European beech in nature (Hendry et al., 1998; Nugent et al., 2005). The growth and virulence of xylariaceous wood-decay fungi is favored by warm temperatures (Hendry et al., 2002) and prolonged summer drought (Luchi et al., 2015). In vitro, Bi. nummularia is capable of rapid growth at $30^{\circ} \mathrm{C}$ (Hendry, 1993). In nature, regional and local distributions of beech trees bearing lesions caused by Bi. nummularia correlate with environmental conditions with low rainfall or high temperatures (Hendry et al., 2002). One explanation for the fact that the necrotic lesions caused by Bi. nummularia are significantly larger than those due to Bi. mediterranea could be that $F$. sylvatica is less sensitive to Bi. mediterranea, which is primarily an oak endophyte (Linaldeddu et al., 2011; Ghasemi et al., 2019) and latent serious oak pathogen (Jurc and Ogris, 2006; Mirabolfathy, 2013). In the case of inoculation with Bi. mediterranea, the sapling started wound-healing, whilst the saplings inoculated with Bi. nummularia did not form callus tissue to overgrow the wood and necroses. Our results on the virulence of $B i$. nummularia against beech reinforce the assessment of Luchi et al. (2015) that this endophyte and latent fungal pathogen is a potential bioindicator of European beech health. The relative success of this species in colonizing large volumes of wood within beech stems in vivo is strongly influenced by abiotic conditions, mainly high temperatures (Hendry et al., 1998). When climatic or host conditions change, the widely distributed endophyte of European beech, Bi. nummularia, can cause dramatic loss of trees and stands, wood-decay, and wood devaluation, thus also weakening trees and adversely affecting occupational safety in the affected beech stands.

Bi. mediterranea is considered a secondary pathogen causing the disease only in stressed hosts (Henriques et al., 2015), especially those suffering from drought stress (Mirabolfathy, 2013). In Germany, Bi. mediterranea has been found in association with shoot dieback, necrosis and wood decay of beech in the course of VLB (Langer et al., 2020; Langer and Bußkamp, 2021). The lifestyle switch to pathogenic behavior is often associated with prolonged periods of stress of the host tree (Henriques et al., 2014). Bi. mediterranea is able to grow rapidly in the xylem and bark host tissues and can cause necrosis, canker and wood decay leading to accelerated tree decline and death (Henriques et al., 2015). Our research confirms this information to the extent that Bi. mediterranea has the capacity to cause necrosis on F. sylvatica-saplings and is able to colonize the host tissue. This is in accordance with the results of Mirabolfathy et al. (2011), who found Bi. mediterranea to be virulent and causing disease symptoms on seedlings of Quercus castaneifolia C.A.Mey. in a similarly designed pathogenicity test. The virulence of $B i$. mediterranea against beech under our test conditions was similar to $H$. fragiforme, Neo. ditissima, and S. sapinea but distinctly less than Bi. nummularia and the other test strains. Although, the two major factors - precipitation (positive correlation) and the temperature (negative correlation) - have a significant influence on the dispersal of Bi. mediterranea spores, host tissue colonization and disease outbreaks, necrosis formation seems to be promoted by water stress in the host tree (Capretti and Battisti, 2007). Results presented by Vannini et al. (2008) suggest that rapid endophytic growth of Bi. mediterranea is favored by a decrease in host water potential, a factor which was not recorded in our experiment. Drought stress of host trees intensifies the effects of charcoal disease (Ghanbary et al., 2020), but our test saplings did not suffer from water stress.

\section{Botryosphaeria stevensii, Bo. dothidea, and Sphaeropsis sapinea}

The latent pathogen Bo. stevensii causes cankers, branch dieback, wilting, yellowing and death of leaves and stem necrosis, and can lead to tree mortality (Vajna, 1986; Alves et al., 2004; Slippers and Wingfield, 2007). The shift to its parasitic stage is mainly initiated by water deficiency in the host tissue (HMUELV Hessen, 2011) and its spread seems to be limited by low temperatures (CABI, 2019). Apart from Bo. corticola, Bo. stevensii, induced the longest necrotic lesions of all other tested Botryosphaeriaceae strains during our inoculation experiment. This partly fits the results of Langer and Bußkamp (2021), who found that Bo. stevensii caused larger necrotic lesions at an average temperature of $25^{\circ} \mathrm{C}$ than $B$. corticola. At mean temperatures less than optimal for B. stevensii [optimal temperature according Kuch et al. (2014): $25^{\circ} \mathrm{C}$ ] the mean lesion length in planta due to this pathogen is less. These results lead us suggest that the virulence of Bo. stevensii decreases with falling temperatures and the risk of negative impact on tree health due to this species is increasing with climate warming. Previous sporadic occurrences of Bo. stevensii in northern Europe (CABI, 2019) and an increasing incidence in recent years in the Mediterranean region (CABI, 2019) and in Germany (HMUELV Hessen, 2011; LFE, 2016; Langer and Bußkamp, 2021) support this hypothesis. Bo. stevensii may play an important role as one of first fungal causal agents in the disease progression of VLB in the context of climate change.

Bo. dothidea is an endophyte and latent pathogen of global importance with respect to tree health (Crist and Schoeneweiss, 1975; Smith and Stanosz, 2001; Butin, 2011; Piškur et al., 2011; Abdollahzadeh et al., 2014; Marsberg et al., 2017; Langer and Bußkamp, 2021). It seems to be native to Europe (Kehr, 2004; Piškur et al., 2011). The endophytic phase or prolonged latent infection in hosts allows Bo. dothidea to cause disease symptoms rapidly when its hosts become stressed (Marsberg et al., 2017; Langer and Bußkamp, 2021). Decreasing water potential and drought stress can be major factors predisposing host trees to infection by Bo. dothidea (Crist and Schoeneweiss, 1975; Ma et al., 2001). Our results indicate that mean air temperature is probably also an important influence on the species' ability to cause disease symptoms because at lower temperatures it produces significantly smaller lesions (Langer and Bußkamp, 2021). Because the optimal growth temperature for $\mathrm{Bo}$. dothidea strains is in the range 27 $30^{\circ} \mathrm{C}$ (Michailides and Morgan, 1992; Yan et al., 2012), we suggest 
that with increasing mean air temperatures in the context of climate change, more disease outbreaks due to Bo. dothidea are to be expected in Germany.

S. sapinea is a common endophyte and pathogen of pine species, widely distributed both globally (Bihon et al., 2012) and in Germany (Bußkamp et al., 2020). The association of S. sapinea with woody tissues of European beech has been recently reported (Zlatković et al., 2017; Langer and Bußkamp, 2021). Heat and drought seem to have an effect on the ability of $S$. sapinea to infect broadleaved trees because occurrence of this latent pathogen has also been reported from diseased woody tissues of Cork oak in Algeria (Smahi, 2017) and Alnus glutinosa in Germany (Bußkamp et al., 2021). We demonstrated the pathogenicity of S. sapinea to European beech, confirming the results reported by Zlatković et al. (2017) and Smahi (2017). The negative influence of lower temperatures on the virulence of $S$. sapinea has been suggested by Langer and Bußkamp (2021), indicating that this species was not able to induce necrosis on woody beech tissues at a mean air temperature of $11^{\circ} \mathrm{C}$. The role of $S$. sapinea in the progression of VLB and other complex diseases of F. sylvatica in the light of climate change is far from fully understood.

\section{Neonectria ditissima}

In Germany, Neo. ditissima is often associated with rough bark beech, phloem necrosis or beech canker (Grüner and Metzler, 2006) and has primarily been isolated from Fagus, Malus and Salix (Castlebury et al., 2006; Ghasemkhani et al., 2016). The results of the pathogenicity tests with Neo. ditissima and the pre- and post-experiment isolation of fungi associated with the stems of the beech saplings cannot be interpreted unambiguously and raise various questions. The test strain used was originally sampled in 1931 from F. sylvatica and still exhibited good growth in vitro. In contrast to the other strains used, age-related low virulence cannot be ruled out. The necrotic lesions observed on saplings inoculated with Neo. ditissima were significantly smaller than on saplings infected with the other Nectriaceae and healed over within four months of inoculation. Based on the results of re-isolation after inoculation, successful infection of the beech saplings is not guaranteed. When infection was successful and necrotic lesions were induced by Neo. ditissima, the species/strain appeared to be less virulent than the other tested Nectriaceae. Reisolation may have failed because the additional isolated fungi, E. quaternata and Clitopilus sp. could have overgrown the lesions and Neo. ditissima. If the infection with Neo. ditissima failed, the endophyte Eutypella quaternata may have overcome its dormant phase and induced the lesions.

Natural infection with Neo. ditissima takes place by means of ascospores and conidia that settle in host wounds (GómezCortecero et al., 2016). The limiting factor for infection in nature is rainfall, because wet conditions are essential for spore production, spread, germination and infection by Neo. ditissima (Xu and Ridout, 1998; Xu and Robinson, 2010). $\mathrm{Xu}$ and Robinson (2010) reported several factors affecting the incidence of canker and the incubation period, the period between infection and appearance of symptoms. Plant resistance and pathogen virulence are influenced by temperature, wetness and the time of year when inoculation takes place. The incidence of canker caused by Neo. ditissima decreases as the age of the wound increases. From this perspective, the initial conditions for infection and formation of necroses in our study were ideal, because the interval between wounding in our pathogenicity test and inoculation with the test strain was very short, since the mycelial plug was inserted immediately after wounding. In relation to environmental conditions and wetness during the pathogenicity test, there were rather unfavorable conditions for an infection because it was significantly warmer and drier in Germany compared to the long-term mean (NW-FVA, 2021).

\section{Hypoxylon fragiforme}

The wood-decaying species $H$. fragiforme is a common endophytic fungus in angiosperm woody tissues (Parfitt et al., 2010) but also occurs as an endophyte in gymnosperms, especially in Scots pine (Bußkamp et al., 2020). The transient endophytic lifestyle of $H$. fragiforme originating from xylem tissue, allows this fungus to progress on to saprotrophic wood-decay activity (Parfitt et al., 2010). Next to Bi. nummularia and Neo. coccinea, $H$. fragiforme is one of the three most common latent fungi in woody tissues of beech (Chapela and Boddy, 1988; Chapela, 1989), occurring in twigs, branches, and stems of European beech (Hendry et al., 2002). Usually, H. fragiforme can be seen fruiting with its anamorph or teleomorph (Red cushion Hypoxylon) in clusters on the bark of dead beech or dead areas on living trees. The results of our pathogenicity tests confirm those reported by Hendry et al. (2002) that $H$. fragiforme is able to form necrotic lesions on beech. The lesions induced by $H$. fragiforme were significantly smaller during our experiment under elevated temperatures than caused by Bi. nummularia. This fits the results of Hendry et al. (2002) who found that the development of $H$. fragiforme decreased at temperatures between 25 and $30^{\circ} \mathrm{C}$. $H$. fragiforme appeared to be less virulent against beech than the other Xylariales species and co-occurred with Neo. coccinea.

\section{CONCLUSION AND OUTLOOK}

Latent plant pathogenic fungi of beech that exhibit endophytic behavior, such as Neo. coccinea, Bi. nummularia, Bo. corticola, Bo. dothidea, Bo. stevensii, and E. quaternata, are sensitive to changes in host physiology driven by stress conditions, as predicted by Desprez-Loustau et al. (2006). However, the relative success of these species in planta is not only strongly influenced by abiotic conditions such as water availability to the host and environmental conditions during infection (e.g., air temperature and humidity), but also biotic factors. These probably include the vigor and resistance of the host, host shift of the pathogen, the vitality, age and possible loss of pathogenicity of the tested strains during storage in artificial conditions, but also the co-occurrence of other quiescent fungal species inhabiting the host trees.

The elevated temperatures during our pathogenicity tests, which are a consequence of the current climate change in Germany, favored establishment and growth of the earlycolonizing species, e.g., Neo. coccinea, Bi. nummularia and plant pathogens, such as Bo. corticola, Nec. cinnabarina, or E. quaternata. Latency units, mainly of Neo. coccinea, appeared to be activated by the host stressors wounding and/or inoculation 
with fungal species. The observations made in our pathogenicity tests do not allow definitive statements regarding the interactions between the co-occurring fungi and the impact on necrosis formation. Because it is not possible to obtain test saplings without endophytes, it is important in the future to carry out co-occurrence studies or antagonist tests in vitro with latent pathogens. In addition, any experiments should be repeated under different temperature conditions and different water availabilities for the host trees.

\section{DATA AVAILABILITY STATEMENT}

The datasets presented in this study can be found in online repositories. The names of the repository/repositories and accession number(s) can be found below: https://www.ncbi.nlm. nih.gov/genbank/, MT561410; https:/www.ncbi.nlm.nih.gov/ genbank/, MT561409; https://www.ncbi.nlm.nih.gov/genbank/, MT561409; https://www.ncbi.nlm.nih.gov/genbank/, MN698983; https://www.ncbi.nlm.nih.gov/genbank/, MZ045841; https:// www.ncbi.nlm.nih.gov/genbank/, MN698981; https://www. ncbi.nlm.nih.gov/genbank/, MZ045842; https://www.ncbi.nlm. nih.gov/genbank/, MZ045843; https://www.ncbi.nlm.nih.gov/ genbank/, MN698988; https://www.ncbi.nlm.nih.gov/genbank/, JF735309; https://www.ncbi.nlm.nih.gov/genbank/, MN698984; https://www.ncbi.nlm.nih.gov/genbank/, MZ045858; https:// www.ncbi.nlm.nih.gov/genbank/, MZ045857; https://www. ncbi.nlm.nih.gov/genbank/, MZ045844; https://www.ncbi.nlm. nih.gov/genbank/, MZ045845; https:/www.ncbi.nlm.nih.gov/ genbank/, MZ045846; https://www.ncbi.nlm.nih.gov/genbank/, MZ045847; https://www.ncbi.nlm.nih.gov/genbank/, MZ045848; https://www.ncbi.nlm.nih.gov/genbank/, MZ045849; https:// www.ncbi.nlm.nih.gov/genbank/, MZ045850; https://www. ncbi.nlm.nih.gov/genbank/, MZ045851; https://www.ncbi.nlm.

\section{REFERENCES}

Abdollahzadeh, J., Hosseini, F., and Javadi, A. (2014). New records from Botryosphaeriaceae (Ascomycota) for mycobiota of Iran. Mycol. Iran. 1, 43-51. doi: $10.22043 / \mathrm{mi} .2014 .4180$

Altschul, S., Madden, T. L., Schaffer, A., Zhang, J., Zhang, Z., Miller, W. E., et al. (1997). Gapped BLAST and PSI-BLAST: a new generation of protein databases search programs. Nucleic Acids Res. 25, 3389-3402. doi: 10.1093/nar/25.17.3389

Alves, A., Correia, A., Luque, J., and Phillips, A. (2004). Botryosphaeria corticola sp. nov. on Quercus species, with notes and description of Botryosphaeria stevensii and its anamorph, Diplodia mutila. Mycologia 96, 598-613. doi: 10. 1080/15572536.2005.11832956

Bartsch, N., von Lüpke, B., and Röhrig, E. (2020). Waldbau auf Ökologischer Grundlage, 8th Edn. (Stuttgart: Eugen Ulmer), 676.

Baum, S., Sieber, T., Schwarze, F., and Fink, S. (2003). Latent infections of Fomes fomentarius in the xylem of European beech (Fagus sylvatica). Mycol. Prog. 2, 141-148. doi: 10.1007/s11557-006-0052-5

Bihon, W., Slippers, B., Burgess, T., Wingfield, M. J., and Wingfield, B. D. (2012). Diverse sources of infection and cryptic recombination revealed in South African Diplodia pinea populations. Fungal Biol. 116, 112-120. doi: 10. 1016/j.funbio.2011.10.006

BMEL (2018). Holzmarktbericht2018.pdf. Available online at: https: //www.bmel.de/SharedDocs/Downloads/Broschueren/Holzmarktbericht2018. pdf?__blob=publicationFile (accessed October 8, 2019). nih.gov/genbank/, MZ045852; https://www.ncbi.nlm.nih.gov/ genbank/, MZ045853; https://www.ncbi.nlm.nih.gov/genbank/, MZ045854; https://www.ncbi.nlm.nih.gov/genbank/, MZ045855; https://www.ncbi.nlm.nih.gov/genbank/, MZ045856; https:// www.ncbi.nlm.nih.gov/genbank/, MZ045914; https://www.ncbi. nlm.nih.gov/genbank/, MZ573778.

\section{AUTHOR CONTRIBUTIONS}

JB organized the implementation and evaluation of the experiment and performed statistical analysis of the results. GL and JB discussed the results and prepared the manuscript. GL wrote the first draft of the manuscript. Both authors designed the concept of the research attempt and undertook identification of the fungi.

\section{FUNDING}

Only budget from the NW-FVA was used to conduct the study and the beech saplings were donated by the local forest department Münden of the Niedersächsische Landesforsten.

\section{ACKNOWLEDGMENTS}

We are grateful for the great technical support from Martina Hille, Annette Ihlemann in the laboratory and from Ursula Rabel in the field during the project and thank Stephanie Hink, Peter Gawehn, Kerstin Herwig, and Etta Paar for technical support. We thank Sees-editing Ltd. for linguistic improvement of the manuscript. We offer many thanks to the reviewers and the editor for improving this manuscript.

Bohn, U., Neuhäusl, R., Gollub, G., Hettwer, C., Neuhäuslová, Z., Raus, T. H., et al. (2003). Karte der Natürlichen Vegetation Europas / Map of the Natural Vegetation of Europe. Maßstab / Scale 1:2500000. (2000/2003). Münster: Landwirtschaftsverlag.

Boyer, J. S. (1995). Biochemical and biophysical aspects of water deficits and the predisposition to disease. Annu. Rev. Phytopathol. 33, 251-274. doi: 10.1146/ annurev.py.33.090195.001343

Butin, H. (2011). Krankheiten der Wald- und Parkbäume - Diagnose, Biologie, Bekämpfung. (Stuttgart: Eugen Ulmer), 319.

Bußkamp, J., Blumenstein, K., Terhonen, E., and Langer, G. J. (2021). Differences in the virulence of Sphaeropsis sapinea strains originating from Scots pine and non-pine hosts. For. Pathol. 4. doi: 10.1111/efp.12712

Bußkamp, J., Langer, G. J., and Langer, E. J. (2020). Sphaeropsis sapinea and fungal endophyte diversity in twigs of Scots pine (Pinus sylvestris) in Germany. Mycol. Prog. 19, 985-999. doi: 10.1007/s11557-020-01617-0

CABI (2019). Botryosphaeria stevensii (Botryosphaeria disease, grapevine). Available online at: https://www.cabi.org/isc/datasheet/9634\#toDistributionMaps (accessed November 21, 2019).

Capretti, P., and Battisti, A. (2007). Water stress and insect defoliation promote the colonization of Quercus cerris by the fungus Biscogniauxia mediterranea. For. Pathol. 37, 129-135. doi: 10.1111/j.1439-0329.2007.00489.x

Castlebury, L. A., Rossman, A. Y., and Hyten, A. S. (2006). Phylogenetic relationships of Neonectria/Cylindrocarpon on Fagus in North America. Can. J. Bot. 84, 1417-1433. doi: 10.1139/b06-105 
Chapela, I. H. (1989). Fungi in healthy stems and branches of American beech and aspen: a comparative study. New Phytol. 113, 65-75. doi: 10.1111/j.1469-8137. 1989.tb02396.x

Chapela, I. H., and Boddy, L. (1988). Fungal colonization of attached beech branches. New Phytol. 110, 47-57. doi: 10.1111/j.1469-8137.1988.tb00236.x

Crist, C., and Schoeneweiss, D. (1975). The influence of controlled stresses on susceptibility of European white birch stems to attack by Botryosphaeria dothidea. Phytopathology 65, 369-373.

Danti, R., Sieber, T. N., and Sanguineti, G. (2002). Endophytic mycobiota in bark of European beech (Fagus sylvatica) in the Apennines. Mycol. Res. 106, 1343-1348. doi: 10.1017/S0953756202006779

Desprez-Loustau, M.-L., Marçais, B., Nageleisen, L.-M., Piou, D., and Vannini, A. (2006). Interactive effects of drought and pathogens in forest trees. Ann. For. Sci. 63, 597-612. doi: 10.1051/forest:2006040

Dreaden, T. J., Shin, K., and Smith, J. A. (2011). First Report of Diplodia corticola causing Branch cankers on Live oak (Quercus virginiana) in Florida. Plant Dis. 95, 1027-1027. doi: 10.1094/PDIS-02-11-0123

Eichhorn, J., Sutmöller, J., Scheler, B., Wagner, M., Dammann, I., Meesenburg, H., et al. (2020). Extreme Witterung der Jahre 2018 und 2019 in Nordwestdeutschland. AFZ-DerWald 75, 26-30.

Ellenberg, H. (1996). Vegetation Mitteleuropas mit den Alpen, 5th Edn. Stuttgart: Ulmer Verlag.

Evans, A. S. (1976). Causation and disease: the Henle-Koch postulates revisited. Yale J. Biol. Med. 49, 175-195.

Friedrich, K., and Kaspar, F. (2019). Rückblick auf das Jahr 2018 - das bisher wärmste Jahr in Deutschland. Report of the German Weather service (DWD). Hamburg: Abteilung Klimaüberwachung.

Ghanbary, E., Kouchaksaraei, M. T., Zarafshar, M., Bader, K.-F. M., Mirabolfathy, M., and Ziaei, M. (2020). Differential physiological and biochemical responses of Quercus infectoria and Q. libani to drought and charcoal disease. Physiol. Plant. 168, 876-892. doi: 10.1111/ppl.13027

Ghasemi, S., Khodaei, S., Karimi, K., Tavakoli, M., Pertot, I., and Arzanlou, M. (2019). Biodiversity study of endophytic fungi associated with two Quercus species in Iran. For. Syst. 28:e003. doi: 10.5424/fs/201928114528

Ghasemkhani, M., Gustavsson, L., Liljeroth, E., and Nybom, H. (2016). Assessment of diversity and genetic relationships of Neonectria ditissima: the causal agent of fruit tree canker. Hereditas 153:7. doi: 10.1186/s41065-016-0011-3

Gómez-Cortecero, A., Saville, R. J., Scheper, R. W. A., Bowen, J. K., Agripino De Medeiros, H., Kingsnorth, J., et al. (2016). Variation in Host and Pathogen in the Neonectria/Malus interaction; toward an understanding of the genetic basis of resistance to European canker. Front. Plant Sci. 7:1365. doi: 10.3389/fpls.2016. 01365

Grüner, J., and Metzler, B. (2006). "Nectria-Arten an Buchenrinde mit Phloemnekrosen," in Strategien zur Sicherung von Buchenwäldern, eds R. Petercord and J. Block (Trippstadt: FAWF), 129-138.

Hendry, S. J. (1993). Strip-Cankering in Relation to the Ecology of Xylariaceae and Diatrypaceae in beech (Fagus sylvatica L.). Ph.D. thesis. Cardiff: University of Wales.

Hendry, S. J., Boddy, L., and Lonsdale, D. (2002). Abiotic variables effect differential expression of latent infections in beech (Fagus sylvatica). New Phytol. 155, 449-460. doi: 10.1046/j.1469-8137.2002.00473.x

Hendry, S. J., Lonsdale, D., and Boddy, L. (1998). Strip-cankering of beech (Fagus sylvatica): pathology and distribution of symptomatic trees. New Phytol. 140, 549-565. doi: 10.1111/j.1469-8137.1998.00282.x

Henriques, J., Barrento, M., Bonifacio, L., Gomes, A., Lima, A., and Sousa, E. (2014). Factors affecting the dispersion of Biscogniauxia mediterranea in Portuguese Cork Oak Stands. Silva Lusit. 22, 83-97.

Henriques, J., Nóbrega, F., Sousa, E., and Lima, A. (2015). Morphological and genetic diversity of Biscogniauxia mediterranea associated to Quercus suber in the Mediterranean Basin. Rev. Cien. Agrar. 38:166.

Hirooka, Y., Rossman, A. Y., and Chaverri, P. (2011). A morphological and phylogenetic revision of the Nectria cinnabarina species complex. Stud. Mycol. 68, 35-56. doi: 10.3114/sim.2011.68.02

Hirooka, Y., Rossman, A. Y., Zhuang, W.-Y., Salgado-Salazar, C., and Chaverri, P. (2013). Species delimitation for Neonectria coccinea group including the causal agents of beech bark disease in Asia, Europe, and North America. Mycosystema 32, 485-517.
HMUELV Hessen (2011). Rindenbrand bei Apfel. Hessisches Ministerium für Umwelt, Klimaschutz, Landwirtschaft und Verbraucherschutz. Available online at: https://www.zlg.de/arzneimittel/deutschland/laenderbehoerden/hessen?tx wwzlgimport_fe1\%5Binst\%5D=1147\&tx_wwzlgimport_fe1\%5Bregion\%5D= Hessen\&cHash=68f9f659933fd4664fb95f6ffa940c08 (accessed November 28, 2019).

Imbery, F., Kaspar, F., Friedrich, K., and Plückhahn, B. (2021). Klimatologischer Rückblick auf 2020: Eines der Wärmsten Jahre in Deutschland und Ende des bisher Wärmsten Jahrzehnts. Report of the German Weather service (DWD). Available online at: https://www.dwd.de/DE/leistungen/besondereereignisse/ temperatur/20210106_rueckblick_jahr_2020.pdf?_blob=publicationFile\&v=7 (accessed June 10, 2021).

Izumitsu, K., Hatoh, K., Sumita, T., Kitade, Y., Morita, A., Tanaka, C., et al. (2012). Rapid and simple preparation of mushroom DNA directly from colonies and fruiting bodies for PCR. Mycoscience 53, 396-401.

Jurc, D., and Ogris, N. (2006). First reported outbreak of charcoal disease caused by Biscogniauxia mediterranea on Turkey oak in Slovenia. Plant Pathol. 55, 299-299. doi: 10.1111/j.1365-3059.2005.01297.x

Karadžić, D., Stanivuković, Z., Milanović, S., Sikora, K., Radulović, Z., Račko, V., et al. (2020). Development of Neonectria punicea Pathogenic Symptoms in Juvenile Fraxinus excelsior Trees. Front. Plant Sci. 11:592260. doi: 10.3389/fpls. 2020.592260

Kaspar, F., and Friedrich, K. (2020). Rückblick auf die Temperatur in Deutschland im Jahr 2019 und die langfristige Entwicklung. Report of the German Weather service (DWD) Abteilungen für Klimaüberwachung und Agrarmeteorologie. Available online at: https://www.dwd.de/DE/leistungen/besondereereignisse/ temperatur/20200102_bericht_jahr2019.pdf?_blob=publicationFile\&v=7 (accessed June 10, 2021).

Kehr, R. (2004). Triebschäden an Mammutbaum (Sequoiadendron giganteum) durch Botryosphaeria dothidea auch in Deutschland nachgewiesen. Nachr. Dtsch. Pflanzenschutzd. 56, 37-43. doi: 10.4267/2042/26392

Kölling, C. (2007). Klimahüllen für 27 Waldbaumarten. AFZ Der Wald 2, 1242 1245.

Kuch, J., Cech, T. L., Konrad, H., and Bedlan, G. (2014). Erstnachweis von Diplodia mutila an Ligustrum vulgare - Beiträge zur Taxonomie von Botryosphaeria stevensii Shoemaker. J. Kulturpflanzen 66, 136-143.

Langer, G. J. (1994). Die gattung botryobasidium DONK (corticiaceae,basidiomycetes). Bibliotheca mycologica. J. Cramer, 158, 459.

Langer, G. J. (2019). Komplexe Erkrankungen bei älteren Rotbuchen. AFZ Der Wald 74, 32-35.

Langer, G. J., and Bußkamp, J. (2021). Botryosphaeriaceae diseases: emerging threats to european beech in germany in the context of global warming and vitality loss of beech. For. Pathol. (submitted under review).

Langer, G. J., Bußkamp, J., Blumenstein, K., and Terhonen, E. (2021). "Fungi inhabiting woody tree tissues - stems, branches, and twigs," in Forest Microbiome Forest Microbiology. Forest Microbiology, Tree Microbiome: Phyllosphere, Endosphere, and Rhizosphere, Vol. 1, eds F. O. Asiegbu and A. Kovalchuk, 175-197.

Langer, G. J., Bußkamp, J., and Langer, E. J. (2020). Absterbeerscheinungen bei Rotbuche durch Wärme und Trockenheit. AFZ Der Wald 75, 24-27.

LFE (2016). Diagnose Report - Diagnostische Arbeiten unter besonderer Berücksichtigung pilzlicher Organismen. Available online at: https: //forst.brandenburg.de/sixcms/media.php/9/diagn_16.pdf (accessed June 4, 2020).

Linaldeddu, B., Costantino, S., Spano, D., and Franceschini, A. (2011). Variation of endophytic cork oak-associated fungal communities in relation to plant health and water stress. For. Pathol. 41, 193-201. doi: 10.1111/j.1439-0329.2010.00 652.x

Linaldeddu, B. T., Scanu, B., Maddau, L., and Franceschini, A. (2014). Diplodia corticola and Phytophthora cinnamomi: the main pathogens involved in holm oak decline on Caprera Island (Italy). For. Pathol. 44, 191-200. doi: 10.1111/ efp.12081

Line, J. (1922). The parasitism of Nectria cinnabarina (coral spot), with special reference to its action on red currant. Trans. Br. Mycol. Soc. 8:22. doi: 10.1016/ S0007-1536(22)80005-X

Luchi, N., Capretti, P., Feducci, M., Vannini, A., Ceccarelli, B., and Vettraino, A. M. (2015). Latent infection of Biscogniauxia nummularia in Fagus sylvatica: a 
possible bioindicator of beech health conditions. iForest 9, 49-54. doi: 10.3832/ ifor1436-008

Ma, Z., Morgan, D. P., and Michailides, T. J. (2001). Effects of Water Stress on Botryosphaeria Blight of Pistachio Caused by Botryosphaeria dothidea. Plant Dis. 85, 745-749. doi: 10.1094/PDIS.2001.85.7.745

Marsberg, A., Kemler, M., Jami, F., Nagel, J., Postma, A., Naidoo, S., et al. (2017). Botryosphaeria dothidea?: a latent pathogen of global importance to woody plant health. Mol. Plant Pathol. 18, 477-488. doi: 10.1111/mpp.12495

Michailides, T. J., and Morgan, D. P. (1992). Effects of temperature and wetness duration on infection of pistachio by Botryosphaeria dothidea and management of disease by reducing duration of irrigation. Phytopathology 82, 1399-1406. doi: 10.1094/phyto-82-1399

Mirabolfathy, M. (2013). Outbreak of charcoal disease on Quercus spp. and Zelkova carpinifolia trees in forests of Zagros and Alborz mountains in Iran. Iran. J. Plant Pathol. 492, 77-79.

Mirabolfathy, M., Groenewald, J. Z., and Crous, P. (2011). The Occurrence of Charcoal Disease Caused by Biscogniauxia mediterranea on Chestnut-Leaved Oak (Quercus castaneifolia) in the Golestan Forests of Iran. Plant Dis. 95:876. doi: 10.1094/PDIS-03-11-0153

Niesar, M., Hartmann, G., Kehr, R., Pehl, L., and Wulf, A. (2007). Symptome und Ursachen der aktuellen Buchenrindenerkrankung in höheren Lagen von Nordrhein-Westfalen. Forstarchiv 78, 105-116.

Nugent, L. K., Sihanonth, P., Thienhirun, S., and Whalley, A. J. S. (2005). Biscogniauxia: a genus of latent invaders. Mycologist 19, 40-43. doi: 10.1017/ S0269915X05001060

NW-FVA (2021). Waldschutzinfo Nr. 1/2021 Witterung 2020. Göttingen: Nordwestdeutsche Forstliche Versuchsanstalt. Available online at: https://www.nw-fva.de/fileadmin/user_upload/Abteilung/Waldschutz/ Waldschutz-Infos_2021/Waldschutzinfo_01-2021_Witterung_2020.pdf (accessed March 11, 2021).

Panzavolta, T., Panichi, A., Bracalini, M., Croci, F., Ginetti, B., Ragazzi, A., et al. (2017). Dispersal and propagule pressure of Botryosphaeriaceae species in a declining oak stand is affected by insect vectors. Forests 8:228.

Parfitt, D., Hunt, J., Dockrell, D., Rogers, H. J., and Boddy, L. (2010). Do all trees carry the seeds of their own destruction? PCR reveals numerous wood decay fungi latently present in sapwood of a wide range of angiosperm trees. Fungal Ecol. 3, 338-346. doi: 10.1016/j.funeco.2010.02.001

Petrini, L., and Petrini, O. (1985). Xylariaceous Fungi as Endophytes. Sydowia 28, 216-234.

Piškur, B., Pavlic, D., Slippers, B., Ogris, N., Maresi, G., Wingfield, M. J., et al. (2011). Diversity and pathogenicity of Botryosphaeriaceae on declining Ostrya carpinifolia in Slovenia and Italy following extreme weather conditions. Eur. J. For. Res. 130, 235-249. doi: 10.1007/s10342-010-0424-x

Rodríguez, J., Elissetche, J., and Valenzuela, S. (2011). “Tree Endophytes and Wood Biodegradation," in Endophytes of Forest Trees, eds A. Pirttilä and A. Frank (Dortrecht: Springer), 81-93. doi: 10.1007/978-94-007-1599-8_5

Senanayake, I. C., Jeewon, R., Chomnunti, P., Wanasinghe, D. N., Norphanphoun, C., Karunarathna, A., et al. (2018). Taxonomic circumscription of Diaporthales based on multigene phylogeny and morphology. Fungal Divers. 93, 241-443. doi: $10.1007 / \mathrm{s} 13225-018-0410-\mathrm{z}$

Sieber, T. N. (2007). Endophytic fungi in forest trees: are they mutualists? Fungal Biol. Rev. 21, 75-89. doi: 10.1016/j.fbr.2007.05.004

Sieber, T. N., and Hugentobler, C. (1987). Endophytische Pilze in Blättern und Ästen gesunder und geschädigter Buchen (Fagus sylvatica L.). Eur. J. For. Pathol. 17, 411-425. doi: 10.1111/j.1439-0329.1987.tb01119.x

Slippers, B., and Wingfield, M. J. (2007). Botryosphaeriaceae as endophytes and latent pathogens of woody plants: diversity, ecology and impact. Fungal Biol. Rev. 21, 90-106. doi: 10.1016/j.fbr.2007.06.002

Smahi, H. (2017). Molecular characterization and pathogenicity of Diplodia corticola and other Botryosphaeriaceae species associated with canker and dieback of Quercus suber in Algeria. Mycosphere 8, 1261-1272. doi: 10.5943/ mycosphere $/ 8 / 2 / 10$

Smith, D., and Stanosz, G. (2001). Molecular and Morphological Differentiation of Botryosphaeria dothidea (Anamorph Fusicoccum aesculi) from Some Other
Fungi with Fusicoccum Anamorphs. Mycologia 93, 505-515. doi: 10.2307/ 3761736

Tamura, K., Peterson, D., Peterson, N., Stecher, G., Nei, M., and Kumar, S. (2011). MEGA5: Molecular evolutionary genetics analysis using maximum likelihood, evolutionary distance, and maximum parsimony methods. Mol. Biol. Evol. 28, 2731-2739.

Tijdeman, E., and Menzel, L. (2021). The development and persistence of soil moisture stress during drought across southwestern Germany. Hydrol. Earth Syst. Sci. 25, 2009-2025. doi: 10.5194/hess-25-2009-2021

Tüxen, R., and Preising, E. (1956). Die Heutige Potentielle Natürliche Vegetation als Gegenstand der Vegetationskartierung: Mit 10 Tabellen. Zentralstelle für Vegetationskartierung, 1956. Available online at: https://katalogbeta.slubdresden.de/id/0-107342670X/

Vajna, L. (1986). Branch canker and dieback of sessile oak (Quercus petraea) in Hungary caused by Diplodia mutila. 1: Identification of the pathogen. Eur. J. For. Pathol 16, 223-229.

Vannini, A., Lucero, G., Anselmi, N., and Vettraino, A. M. (2008). Response of endophytic Biscogniauxia mediterranea to variation in leaf water potential of Quercus cerris. For. Pathol. 39, 8-14. doi: 10.1111/j.1439-0329.2008.00 554.x

Vasilyeva, L. (2011). Quaternaria carpinicola, a comb. nov. (Diatrypaceae). Mycosphere 2, 515-517.

Vasilyeva, L., and Scheuer, C. (1996). Neuere Aufsammlungen stromatischer Pyrenomyceten aus Österreich, insbesondere der Steiermark. Mitt. Naturwiss. Ver. Steiermark, Band 126, 61-82.

Whalley, A. J. S. (1996). The xylariaceous way of life. Mycol. Res. 100, 897-922. doi: 10.1016/s0953-7562(96)80042-6

White, T. J., Bruns, T., Lee, S., and Taylor, J. (1990). “Amplification and direct sequencing of fungal ribosomal RNA genes for phylogenetics," in PCR Protocols: A Guide to Methods and Applications. PCR Protoc. A Guide Methods Appl, Vol. 18, eds M. A. Innis, D. H. Gelfand, J. J. Sninsky, and T. J. White, 315-322.

$\mathrm{Xu}, \mathrm{X}$., and Robinson, J. (2010). Effects of fruit maturity and wetness on the infection of apple fruit by Neonectria galligena: Infection of apple fruit by N. galligena. Plant Pathol. 59, 542-547. doi: 10.1111/j.1365-3059.2009.02 232.X

Xu, X.-M., and Ridout, M. S. (1998). The effects of inoculum dose, duration of wet period, temperature and wound age on infection by Nectria galligena of pruning wounds on apple. Eur. J. Plant Pathol. 104, 511-519. doi: 10.1023/A: 1008689406350

Yan, J., Xie, Y., Yao, S., Wang, Z., and Li, X. (2012). Characterization of Botryosphaeria dothidea, the causal agent of grapevine canker in China. Aust. Plant Pathol. 41, 351-357. doi: 10.1007/s13313-012-0 135-5

Zlatković, M., Keča, N., Wingfield, M. J., Jami, F., and Slippers, B. (2017). New and unexpected host associations for Diplodia sapinea in the Western Balkans. For. Pathol. 47:e12328. doi: 10.1111/efp.12328

Conflict of Interest: The authors declare that the research was conducted in the absence of any commercial or financial relationships that could be construed as a potential conflict of interest.

Publisher's Note: All claims expressed in this article are solely those of the authors and do not necessarily represent those of their affiliated organizations, or those of the publisher, the editors and the reviewers. Any product that may be evaluated in this article, or claim that may be made by its manufacturer, is not guaranteed or endorsed by the publisher.

Copyright (C) 2021 Langer and Bußkamp. This is an open-access article distributed under the terms of the Creative Commons Attribution License (CC BY). The use, distribution or reproduction in other forums is permitted, provided the original author(s) and the copyright owner(s) are credited and that the original publication in this journal is cited, in accordance with accepted academic practice. No use, distribution or reproduction is permitted which does not comply with these terms. 